The Effect of Science on the Second World War 
Also by Guy Hartcup

CAMOUFlaGE: A History of Concealment and Deception in War COCKCROFT AND THE ATOM (with T. E. Allibone)

CODE NAME MULBERRY: The Planning, Building and Operation of the Normandy Harbours

THE ACHIEVEMENT OF THE AIRSHIP: A History of the Development of Rigid, Semi-rigid and Non-rigid Airships

THE CHALLENGE OF WAR: Scientific and Engineering Contributions to World War 2

THE ORIGINS AND DEVEIIOPMENT OF OPERATIONAL RESI:ARCH IN THE RAF

THE SILENT REVOL.UTION: Development of Conventional Weapons, 1945-85

THE WAR OF INVENTION: Scientific Developments, 1914-18 


\title{
The Effect of Science on the Second World War
}

\author{
Guy Hartcup
}


First published in Great Britain 2000 by

\section{MACMILLAN PRESS LTD}

Houndmills, Basingstoke. Hampshire RG21 6XS and London

Companies and representatives throughout the world

A catalogue record for this book is available from the British Library.

ISBN 978-1-349-39876-8ＩSBN 978-0-230-38987-8 (eBook)

DOI $10.1057 / 9780230389878$

First published in the United States of America 2000 by

\section{ST. MARTIN'S PRESS, INC.}

Scholarly and Reference Division.

175 Fifth Avenue, New York. N.Y. 10010

Library of Congress Cataloging-in-Publication Data

Hartcup. Guy.

The effect of science on the second World War / Guy Harteup.

p. cm.

Includes bibliographical references and index.

1. World War. 1939-1945-Science. I. Title.

D810.S2 H.37 2000

(9) $40.53-\mathrm{k} k 21$

$99-054609$

() Guy Hartcup $200(0$

Softcover reprint of the hardcover 1st edition 2000 978-0-333-67061-3

All rights reserved. No reproduction. copy or transmission of this publication may be made without written permission.

No paragraph of this publication may be reproduced copied or transmitted salve with written permission or in accordance with the provisions of the Copyright. Designs and Patents Act 1988 , or under the terms of any licence permitting limited copying issued by the Copyright Licensing Agency. 90 Tottenham Court Road. London W1P (LP.

Any person who does any unathorised act in relation to this publication may be liable to criminal prosecution and civil claims for damages.

The author hats atserted his right to be identified at the author of this work in accordance with the Copyright, Designs and Patents Act 1988.

This book is printed on paper suitable for recycling and made from fully managed and sustained forest sources.

$\begin{array}{rrrrrrrrrr}10 & 9 & 8 & 7 & 6 & 5 & + & 3 & 2 & 1 \\ 09 & 08 & 07 & 06 & 05 & 04 & 03 & 03 & 01 & 00\end{array}$

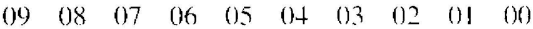


For Freddie and the rest of the family 
This page intentionally left blank 


\section{Contents}

List of Plates $\quad$ ix

Acknowledgements $\quad x$

Introduction $\quad x \mathrm{i}$

1 Organization of Science for War 1

2 Radar: Defence and Offence 18

3 Diverse Applications of Radio and Radar 39

4 Acoustic and Underwater Warfare 60

5 The Acquisition of Signals Intelligence 82

6 Birth of a New Science: Operational Research 100

7 The Transformation of Military Medicine 122

8 Unacceptable Weapons: Gas and Bacteria 138

9 Premature Weapons: the Rocket and the Jet 152

10 The Ultimate Weapon: the Atomic Bomb 169

$\begin{array}{ll}\text { Conclusion } & 185\end{array}$

$\begin{array}{ll}\text { Notes } & 188\end{array}$

Bibliography $\quad 202$

$\begin{array}{ll}\text { Index } & 205\end{array}$ 
This page intentionally left blank 


\section{List of Plates}

1. Sir Henry 'Tizard. Architect of the British radar chain and leader of the mission to the USA in August 1940. Imperial College Archives

2. Winston Churchill and F. A. Lindemann (later Lord Cherwell), his scientific adviser throughout the war. Imperial War Museum

3. Vannevar Bush. Head of the US Office of Scientific Research and Development and adviser to the President. MIT Museum

4. P. M. S. Blackett. Member of the Tizard Committee and later Chief Adviser on Operational Research in the Admiralty. Universal Picture Press \& Agency Ltd

5. Howard Florey. Chief wartime developer of penicillin. Wellcome Institute Library, London

6. British nuclear physicists. $L$ to $R$ : William Penney (member of Los Alamos team), Otto Frisch, Rudolf Peierls, John Cockcroft (also director of Army radar research until June 1944). UK Atomic Energy Authority

7. Typical Chain Home station. (iEC Journal of Research, vol. 3, no. 2, 1985

8. Strapped magnetron used for naval $10 \mathrm{~cm}$ radar. (IEC Review, vol. 10, no. 1,1995

9. Hedgehog ahead-throwing bomb projector against U-boats. Public Record Office

10. German Enigma machine with plugboard uncovered. Dr Mark Baldwin of $M \& M$ Baldwin publishers

11. V2 rocket being prepared to fire. Royal Aeronautical Socicty

12. Messerschmitt 262 jet-propelled fighter. Imperial War Museum 


\section{Acknowledgements}

As so many applications of science have been covered in this book, I have been dependent on obtaining the comments and criticisms of experts. I am therefore deeply grateful to those who have read so carefully individual chapters, namely Frank Armstrong, Lorna Arnold, G. B. Carter, Ralph Erskine, Lieutenant-Commander W. J. R. Gardner, RN, Dr Norman Heatley and Professor Jonathan Rosenhead. Others who advised or helped me include Professor Ralph Benjamin, John Bradley, David Edgerton, the late Professor R. V. Jones and that nonagenarian and veteran operational researcher, J. R. Vezey. Such errors that remain are my own responsibility. I must also thank Alice Haythornthwaite who admirably did the research for the chapter on medicine.

I am also indebted to the staffs of those invaluable institutions, the Public Record Office, the Science Museum Library, the library of the International Institute of Strategic Studies, the library of the Imperial War Museum and the library of the Royal Aeronautical Society whose Librarian, Arnold Nayler, has, as ever, dug out books and answered questions at short notice.

Finally, I must thank my wife for her forbearance over the past three years while working on the book.

Guy Hartcup

East Sheen

January 1999 


\section{Introduction}

The 50th anniversary of the end of the Second World War was celebrated with a spate of books reviewing the strategy, commanders and the campaigns on land, on sea and in the air. This literature merely added to the torrent of books and TV programmes on the two world wars which continue to flow, finding new material or making revisionist judgements on disputed events. It is surprising therefore that the effect of science on the war has in comparison been neglected. Everyone seems to know that science and technology made an impact on both world wars, more on the second than the first. Most people are aware of radar's contribution to RAF Fighter Command's victory in the Battle of Britain, or of the benefit of penicillin in the treatment of wounds or DDT on tropical diseases. They know that the German V2s did not alter the course of the war, unpleasant weapons though they were, but they are less aware that the V2 was the first step towards the American landing on the moon, or that the guided weapons produced by the Germans in the last months of the war led to the precision weapons that intrigued everyone who followed the Gulf War. Nor are they aware of how both sides organized their scientists, or why the Germans, Italians and Japanese - who were not lacking in scientific ability - failed to help their military, unlike their one-time colleagues in the Allied camp.

The twenty years before the outbreak of war in September 1939 was a period of intense activity in science which was to have an extraordinary effect on warfare. Five developments need to be mentioned. First, radio was transformed when spark transmission was replaced by thermionic valves, opening the way for short-wave, and later ultra-short-wave, communication which had so many military applications. Second, American and British scientists began to measure the height of the ionosphere, a belt some thirty to fifty miles above the earth able to reflect radio waves. These practical steps were a first step towards radar on which some primitive experiments had already taken place. Third, research began on new fuels such as liquid oxygen and hydrogen peroxide which would provide power for rockets and submarines, also on high temperature alloys such as nimonic later used for making jet engines. Fourth, medical research on sulphonamides began and penicillin was accidentally discovered but not yet exploited. That had to wait until the urgent requirements of war compelled action. Finally, the face 
of war itself was to be radically altered by a series of events in the world of physics - the artificial disintegration of the atom in 1919, followed thirteen years later by the discovery of the neutron - particles which, having no electric charge, could pass through matter without being deflected by the forces surrounding nuclei - and then in January 1939 , only nine months before the outbreak of the Second World War, the discovery that the splitting of the uranium atom would release enough energy to explode a bomb.

How was all this knowledge to be translated into weapons of war and how were the scientists to be integrated into the war effort? The way in which the Allies and the Axis powers tackled this problem proved to be vital to the winning of the war.

The history of science in the Second World War has so far been disappointing. In Britain a popular account called Science at War was published in 1947 revealing for the first time details of radar, naval science, operational research and the atomic bomb, but there was no mention of medical research on the grounds that the public had already been told about penicillin and DDT. However, that year a proposal for a more comprehensive scientific history of the war was turned down by the Advisory Committee on Scientific Policy to the Cabinet after being told by the eminent scientist, Sir Edward Appleton, that there would only be a limited demand for such a work which would not justify the research involved. ${ }^{1}$ In its place a volume of the civil official histories titled The Design and Development of Weapons was published in 1963. It surveyed the development of military aircraft (including jet-propelled), army weapons and radar and, perhaps most interesting of all, gave an account of research establishments. Fven so, it did not explain why, to take one example, radar was a success while the development of the tank (a British invention) in the war was, in general, a failure.

In the United States the wartime scientific effort was given more generous recognition with the publication of Scientists against Time by James Phinney Baxter, first published in 1946. It covered all aspects of science in the war and was a masterpiece of compression, though, like the British version, it was a celebratory rather than a critical account.

The most interesting books on science in the Second World War were, in fact, written by the scientists themselves. There were accounts of radar by Watson-Watt who demonstrated its feasibility to the British, A. P. Rowe, head of the Telecommunications Research Establishment (TRE) and by three of his distinguished colleagues, Bernard Lovell, Alan Hodgkin and E. G. Bowen, the 'father' of airborne radar. Solly Zuckerman, eventually to become a Chief Scientific Adviser after the war, showed 
how an anatomist/zoologist could, by treating a military problem in the same way as he would a living organism, be able to provide an acceptable plan to hinder the arrival of enemy reinforcements on the battlefield. R. V. Jones, a physicist, was the first to give a brilliant insight into the working of scientific intelligence. In the States Vannevar Bush wrote a rambling but entertaining volume of reminiscences called Pices of the Action. Accounts of the war by German scientists have been sparse though the conversations recorded by secret microphones of leading nuclear physicists interned after the European war illuminate the state of science under the Nazis.

National security was another obstacle delaying publication of books on science and the war. Officials had to be cautious, on account of the Cold War, about releasing information which, even though dated, might be valuable to a potential enemy. Thus the best kept secret of all - the deciphering of German radio communications by the British under the code name Ultra - had to wait release until the mid-1970s. The breaking of Japanese codes and ciphers known as Magic was much earlier than Ultra. They revealed another side of military science - the construction of the first primitive computers employed to accelerate code breaking. Once more, it was the personal accounts of the classical scholars, mathematicians as well as scientists, that caught the public imagination rather than the weighty but authoritative volumes entitled British Intelligence in the Second World $W$ ar which were published from 1979 onwards.

More recently historians of science and technology have turned their attention to the effect that armed forces and weapons technology has had on society. The two world wars have provided much material to work on. Alongside these studies, analyses written from a more polemical point of view on the effect of war on society, for example the theme of British industrial decline in the twentieth century investigated by Correlli Barnett, continue to engage the attention of historians.

How then does this book fit into the scheme of things? A comprehensive history of science in the Second World War on the lines of that rejected by Sir Edward Appleton is not possible in the space available. What perhaps can be done is to bring the story up to date by comparing the Allied scientific effort with that of the enemy. Instead of describing technicalities, it will try to assess how the intervention of scientists or their devices affected particular operations. Thus radar, sonar and other underwater weapons, missiles and chemical and biological weapons (fortunately never used but which remained a threat) will be covered. Other sides of the scientific war such as operational research, the use of 
science in code and cipher breaking and medical research need attention. The atomic bomb is in a class on its own. It absorbed the energies of the most eminent scientists and because of it warfare was changed irreversibly. Hence it is discussed in the final chapter. What especially needs stressing is that success in the scientific and technical contributions to the Second World War went to the side which recognized the importance of close collaboration between scientists and the military, something unknown before 1939 .

Finally, there is the problem of distinguishing between science and engineering. Many of the war-winning devices were the joint work of scientists and engineers. Indeed, in the development of radar, physicists often became temporary engineers. At the same time there were feats of pure engineering like the construction of the Mulberry harbours for the landings in Normandy in 1944 which fall outside the scope of this study. But there were other advances involving scientists and engineers initiated on account of the war - the long-range rocket and jet propulsion - which had limited or nil effect on its outcome but which were to change the postwar world and therefore need to be discussed. 
War is much too serious a thing to be left to the military.

\section{Georges Clemenceau}

TT/heir inventions are according to right reason even if you don't approve the end to which they proceed.

David Jones, In Parenthesis 